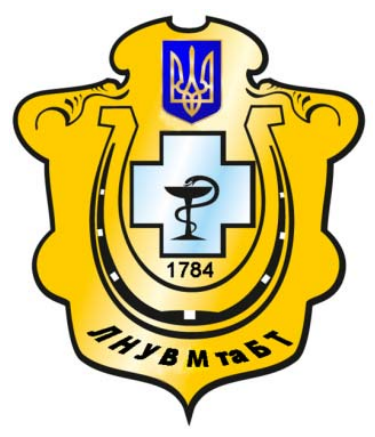

Науковий вісник Львівського національного університету ветеринарної медицини та біотехнологій імені С.3. Гжицького

Scientific Messenger of Lviv National University of Veterinary Medicine and Biotechnologies named after S.Z. Gzhytskyj

doi:10.15421/nvlvet7514

ISSN 2519-268X print

ISSN 2518-1327 online

$\underline{\text { http://nvlvet.com.ua/ }}$

УДК 635. 537.6

\title{
Кваліметрична оцінка органолептичних показників варених ковбас
}

\author{
О.П. Фурсік, I.М. Страшинський \\ fursikoksana@gmail.com
}

\begin{abstract}
Національний університет харчових технологій, вул. Володимирська, 68, м. Київ, 01601, Україна
\end{abstract}

\begin{abstract}
Якість продукиї в даний час є ключовою проблемою усіх галузей харчової промисловості. Органолептичний аналіз в сукупності з кваліметричною оцінкою дозволяє швидко і просто оцінити якість сировини, напівфабрикатів $і$ кулінарної продукиії, виявити відхилення від рецептури, технології виробництва, щэо, у свою чергу, дає можливість оперативно вжити заходів стосовно усунення недоліків. Об' єктом дослідження є зразки варених ковбас, в яких провели заміну м'ясної сировини відповідною кількістю гідратованої білоквмісної композииї (20, 30 та 40\%). До ї̈ складу входять білкові препарати рослинного та тваринного походження, ксантанова та гуарова камідь, а також карбоксиметилиелюлоза.

Провівши органолептичний аналіз варених ковбас за рядом показників можна констатувати переваги дослідних зразків № 1 та № 2 над контрольним. Внесення гідратованої композииї завдяки високому вмісту вологи поліпшує консистенцію та підвищує соковитість, щуо забезпечує приємний смак продукту. У рецептурі № 3 загальна оцінка нижча порівняно із контрольним та дослідними зразками, адже заміна м'ясної сировини значною кількістю гідратованої харчової композицї призводить до утворення рихлої консистениії, щзо погіршує якісні показники.

Використання 30\% гідратованої білоквмісної композиції у рецептурі № 2 свідчить про ефективну заміну м'ясної сировини з одночасним здешевленням готового продукту, що у наш час є не мени актуальним.

Ключові слова: білковмісна композиція, варені ковбаси, органолептичні властивості, кваліметрія, якість.
\end{abstract}

\section{Квалиметрическая оценка органолептических показателей вареных колбас}

\author{
О.П. Фурсик, И.М. Страшинский \\ fursikoksana@gmail.com
}

Нацииональный университет пищевых технологий, ул. Владимирская, 68, г. Киев, 01601, Украина

Качество продукции в настоящее время является ключевой проблемой всех отраслей пищевой промышленности. Органолептический анализ в совокупности с квалиметрической оценкой позволяет быстро и просто оценить качество сырья, полуфабрикатов и кулинарных изделий, выявить отклонения в рецептуре, технологии производства, что, в свою очередь, дает возможность оперативно принять меры по устранению выявленных недостатков. Объектом исследования являются образиь вареных колбас, в которых провели замену мясного сырья соответствующим количеством гидратированной белоксодержащей композичии (20, 30 и 40\%). В ее состав входят белковые препараты растительного и животного происхождения, ксантановая и гуаровая камедь, а также карбоксиметилцеллюлоза.

Проведя органолептический анализ ряда показателей можно констатировать преимущества исследованных рецептур № 1 и № 2 над контрольным образцом. Внесение гидратированной композиции, благодаря высокому содержсанию влаги, улучшает консистенцию и повышает сочность, что обеспечивает приятный вкус продукта. В рецептуре № 3 общая оценка ниже по сравнению с контрольным и опытными образиами, ведь замена мясного сырья значительным количеством гидратированной пищевой композици приводит к образованию рыхлой консистенции, ухудшает качественные показатели. Использование 30\% гидратированной белоксодержащей композици в рещептуре № 2 свидетельствует об эффективной замене мясного сырья с одновременным удешевлением готового продукта, что в наше время не менее актуально.

Ключевые слова: содержащая белок композичия, вареные колбасы, органолептические свойства, квалиметрия, качество.

Citation:

Fursik, O., Strashynskiy, I. (2017). Qualimetric evaluation of organoleptic parameters of cooked sausages. Scientific Messenger LNUVMBT named after S.Z. Gzhytskyj, 19(75), 72-75. 


\title{
Qualimetric evaluation of organoleptic parameters of cooked sausages
}

\author{
O. Fursik, I. Strashynskiy \\ fursikoksana@gmail.com \\ National University of Food Technologies, \\ Volodymyrska Str., 68, Kyiv, 01601, Ukraine
}

The quality of products is a key problem for all branches of the food industry now. The domestic economic situation predetermines the use of food additives both separately and as part of functional compositions. These components differ in properties and in different ways affect the quality of finished products. Organoleptic analysis in conjunction with the qualimetric assessment allows you to quickly and easily assess the quality of raw materials, semi-finished products and culinary products, identify violations of the formulation, production technology, which in turn makes it possible to quickly take action to eliminate the identified shortcomings.

The subject of the study are samples of boiled sausages in which the replacement of meat raw material with a corresponding amount of hydrated protein-containing composition (20, 30 and 40\%) was performed. It consists of plant and animal origin protein preparations, xanthan and guar gum and carboxymethyl cellulose.

Having performed an organoleptic analysis for a number of indicators, it is possible to state the advantages of the investigated formulations No. 1 and No. 2 over the control sample. The introduction of the hydrated composition due to the high moisture content improves the consistency and increases the juiciness, which ensures a pleasant taste of the product. In formulation No. 3, the overall score is lower compared to the control and test samples, because the replacement of meat raw material with a significant amount of hydrated food composition leads to the formation of loose consistency, impairs the quality parameters.

The use of $30 \%$ of the hydrated protein-containing composition in the formulation No. 2 indicates an effective replacement of meat raw materials with a simultaneous reduction in the cost of a finished product, which in our time is no less actuality.

Key words: containing protein composition, cooked sausage, organoleptic properties, qualimetry, quality.

\section{Вступ}

Якість продукції в даний час є ключовою проблемою усіх галузей харчової промисловості. Слід зазначити, що в міру розвитку в нашій країні ринкової економіки якість набуває особливого значення (Syicheva et al., 2010).

Якість сировини, напівфабрикатів і готової продукції визначають на основі характерних для них властивостей, тобто показників якості, які включають органолептичну оцінку.

Органолептичні методи аналізу швидко, об'єктивно і надійно дають загальне враження про якість продуктів. Сенсорний контроль дозволяє оперативно і цілеспрямовано впливати на всі стадії виробництв харчових продуктів.

Результати органолептичної оцінки часто є остаточними і вирішальними при визначенні якості м'яса. Сенсорна оцінка якості продукту може бути диференційованою (за окремими показниками якості) і комплексною, що враховує значення всіх показників дослідного продукту.

Сучасна економічна ситуація зумовлює використання харчових добавок як окремо, так і в складі функціональних композицій. Дані компоненти відрізняються за властивостями і по-різному впливають на якісні показники готових виробів. Дослідженнями встановлено, що внесення ізолятів соєвого, горохового (гідратованих) та концентрату топінамбуру (сухий порошок) в кількості 15-20\%, 10\%, 3-5\% відповідно не здійснює негативного впливу на органолептичні показники і дозволяє істотно поліпшити ніжність і підвищити соковитість готового продукту (Magzumova, 2012).

Науково організований органолептичний аналіз перевершує багато прийомів лабораторних досліджень, особливо щодо таких показників, як смак, запах і консистенція. Помилки виникають при непро- фесійному підході до сенсорних методів оцінки продуктів. Тому для підвищення точності показників і узагальнення отриманих даних використовують кваліметричну оцінку результатів.

Наукова галузь, яка об'єднує кількісні методи оцінки якості, які використовуються для обгрунтування рішень, прийнятих при управлінні якістю продукції і стандартизації, називається кваліметрією.

Особливістю даного методу оцінки якості є кількісне порівняння досліджуваного продукту з еталоном, за який приймається або вже існуючий продукт, або ідеалізований з урахуванням сучасних вимог до харчування продукт - еталон. Кваліметричний аналіз вважається найоб'єктивнішим способом, за допомогою якого можна вибрати і оцінити матеріал.

Під кількісною оцінкою якості продукції розуміють визначення чисельних значень певних показників якості. Така оцінка зазвичай використовується для вибору найоптимальнішого варіанта для планування, контролю, а також для проведення атестації якості готової продукції.

Об'єктом аналізу є продукція, яка піддається кваліметричному аналізу, незалежно від iï виду, призначення і складу (Syicheva et al., 2010).

Мета наших досліджень - порівняння описового i профільного методів органолептичного аналізу дослідних зразків варених ковбас із заміною основної сировини розробленою білоквмісною композицією.

\section{Матеріал і методи дослідження}

При розробці нових видів м'ясних продуктів, що передбачають заміну м'ясної сировини нем'ясними інгредієнтами, необхідною умовою $є$ збереження органолептичних показників, властивих традиційним м'ясним продуктам. Органолептичні показники якості м'ясних виробів передусім оцінюються споживачами 
і в значній мірі впливають на їх конкурентоспроможність і обсяг продаж.

Для виготовлення дослідних зразків варених ковбас використали гідратовану білоквмісну композицію (ступінь гідратації 1:20). До її складу входять білкові препарати рослинного (соєвий ізолят «Pro Vo $500 \mathrm{U»)}$ та тваринного (білок свинячої дерми - Белкотон С95, суха молочна сироватка) походження, ксантанова та гуарова камідь, а також карбоксиметилцелюлоза у визначеному співвідношенні (Strashynskiy et al., 2016).

За контроль було обрано рецептуру варених ковбас, до складу якої входить: яловичина II сорту, свинина напівжирна, м'ясо птиці (червоне куряче м'ясо), шпик (грудний), борошно, меланж, сіль та спеції. На іiї основі розробили рецептури дослідних зразків варених ковбас, в яких провели заміну м'ясної сировини відповідною кількістю гідратованої композиції (20, 30 та $40 \%)$. Гідратацію проводили водою $\left(\mathrm{t}=8-12^{\circ} \mathrm{C}\right)$ у співвідношенні 1:20.

Органолептичні показники варених ковбасних виробів визначали відповідно до стандарту ДСТУ 4436: 2005. Дослідження проводили 9 дегустаторів, які характеризували продукт за шістьма показниками (зовнішній вигляд, колір, запах, консистенція, смак і соковитість). У разі відхилення окремих показників від норми знижують бали. Підготовку до дегустації проводили відповідно до вимог стандарту ДСТУ 4823: 2007.

Органолептичні показники у дослідних зразках оцінювали профільним методом 3 використанням п’ятибальної шкали і графічно зображували у вигляді профілограм.

\section{Результати та їх обговорення}

Для вибору допустимої частки функціональної харчової композиції у рецептурах варених ковбас провели органолептичну оцінку готового продукту, наведену у табл. 1.

Кількісну оцінку якості варених ковбас із заміною м'ясної сировини білоквмісною композицією у порівняні $з$ контрольним зразком провели за комплексом органолептичних показників. Отримавши загальну оцінку за рядом органолептичних показників можна констатувати переваги дослідних рецептур № 1 та № 2 над контрольним зразком, оскільки він мав тверду надто щільну консистенцію та був не соковитим, що відповідно і вплинуло на смак продукту.

Табличя 1

Органолептична оцінка модельних рецептур варених ковбас

\begin{tabular}{|l|c|c|c|c|}
\hline Показники & Контроль & Рецептура № 1 & Рецептура № 2 & Рецептура № 3 \\
\hline Зовнішній вигляд & $4,4 \pm 0,11$ & $4,6 \pm 0,2$ & $4,5 \pm 0,15$ & $4,3 \pm 0,18$ \\
\hline Колір & $4,5 \pm 0,14$ & $4,4 \pm 0,15$ & $4,3 \pm 0,18$ & $3,8 \pm 0,13$ \\
\hline Запах & $4,3 \pm 0,12$ & $4,2 \pm 0,13$ & $4,4 \pm 0,18$ & $4,0 \pm 0,19$ \\
\hline Смак & $4,4 \pm 0,17$ & $4,8 \pm 0,16$ & $4,6 \pm 0,16$ & $3,8 \pm 0,17$ \\
\hline Консистенція & $4,2 \pm 0,12$ & $4,5 \pm 0,17$ & $4,7 \pm 0,14$ & $3,9 \pm 19$ \\
\hline Соковитість & $3,8 \pm 0,16$ & $4,4 \pm 0,14$ & $4,6 \pm 0,11$ & $4,0 \pm 0,19$ \\
\hline Загальна оцінка & $4,27 \pm 0,21$ & $4,48 \pm 0,2$ & $4,52 \pm 0,19$ & $3,97 \pm 0,2$ \\
\hline
\end{tabular}

У рецептурах № 1 і № 2 поліпшення консистенції та соковитості обгрунтовується внесенням композиції, яка завдяки високому вмісту вологи поліпшує консистенцію та підвищує соковитість, а також забезпечує приємний смак продукту. У рецептурі № 3 загальна оцінка нижча порівняно із контрольним та дослідними зразками, адже заміна м'ясної сировини значною кількістю білоквмісної композиції призводить до утворення не щільної консистенції, що погіршує загальні показники. Дані щодо консистенції кількісно характеризуються силою пенетрації, яка наведена в роботі (Strashynskyi et al., 2015).

Зі збільшенням кількості розробленої композиції у складі варених ковбас спостерігалося погіршення кольору, що зумовлено зменшенням кількості м'ясної сировини, у якій міститься міоглобін.

Для визначення якісних відмінностей розробленого продукту органолептичну оцінку доцільно доповнити побудовою профілограм, що дозволить наглядно продемонструвати повну картину порівняльної сенсорної оцінки зразків.

Графічно отримані показники зображені на рис 1.

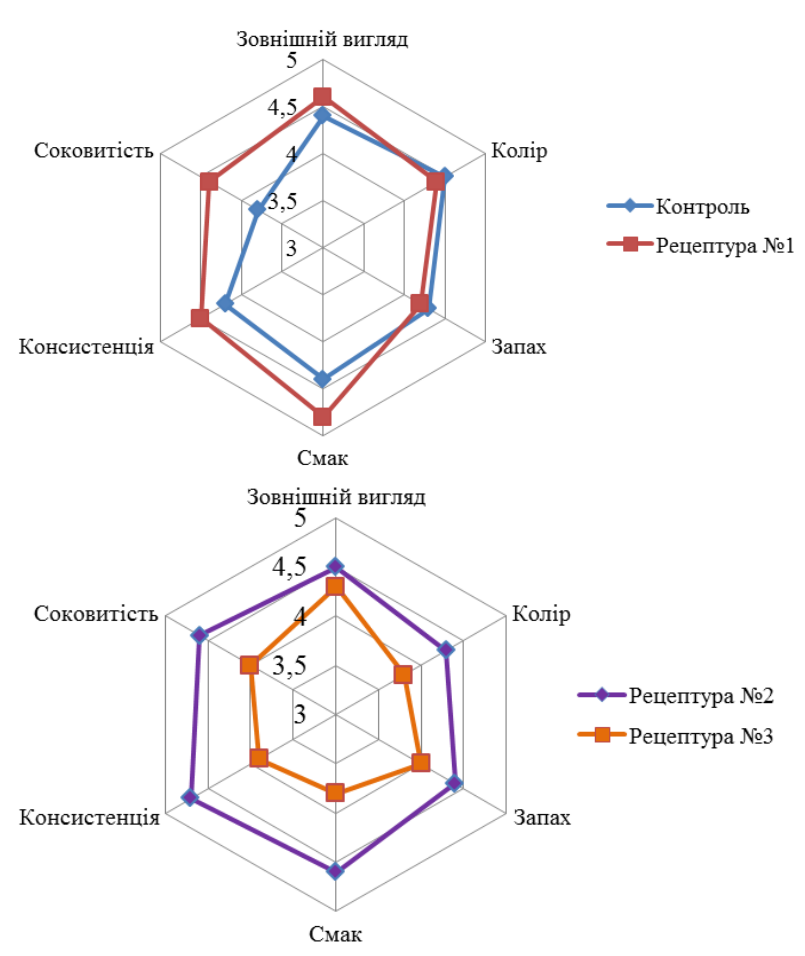

Рис. 1. Органолептичні показники варених ковбас 
На основі отриманих графіків програмою Мicrosoft Office Excel 2007 провели розрахунок площ побудованих профілограм та визначили їх відношен- ня до оптимальної (характерної для продукту з максимальною середньою оцінкою 5,0).

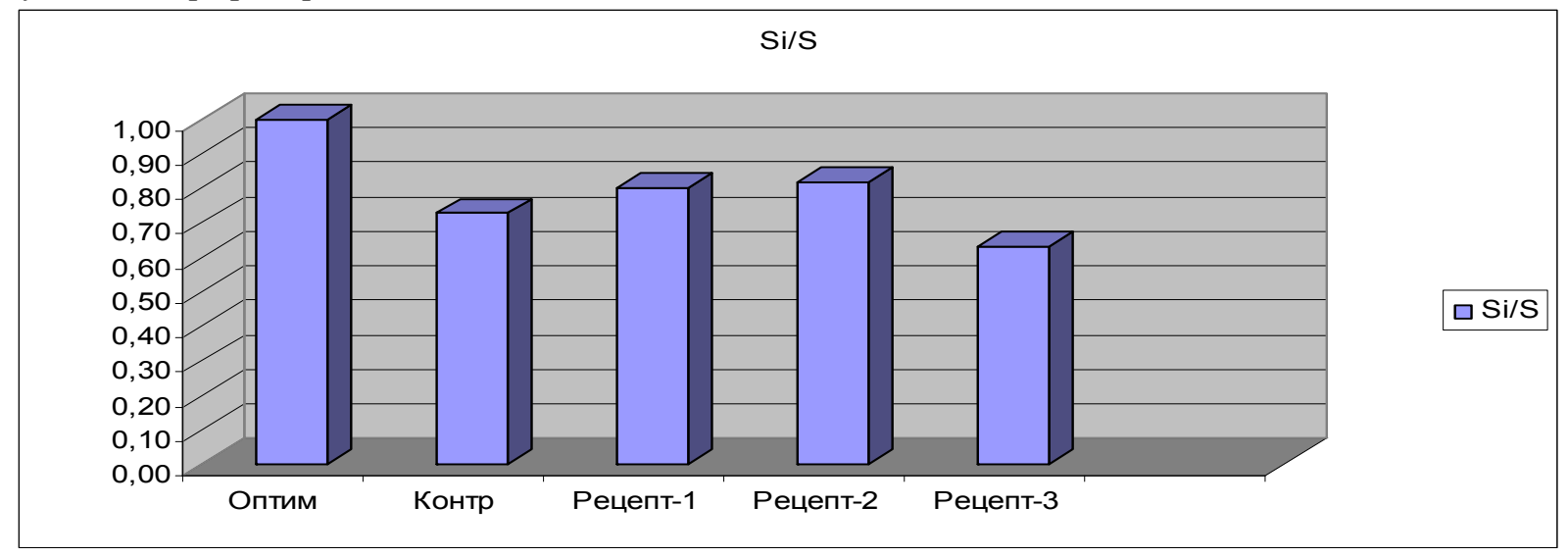

Рис. 2. Відношення площ дослідних зразків до оптимальної

Підрахувавши площі оптимального та дослідних зразків, можна відмітити їх збільшення у рецептурах № 1 та № 2 порівняно 3 контрольним зразком та рецептурою № 3. Профілограми даних рецептур мають майже однакові площі, тому можна стверджувати про ïx високі показники якості, проте найбільше до оптимального значення наближається рецептура № 2, що наочно продемонстровано на рисунку 2.

\section{Висновки}

Підсумовуючи отримані результати комплексу проведених досліджень, можна стверджувати, що заміна м'ясної сировини $30 \%$ білоквмісної композиції дозволяє підвищити показники як функціональнотехнологічних, фізико-хімічних так і органолептичних властивостей. Показники структурно-механічних властивостей обраної рецептури порівняно 3 контрольним зразком та рецептурою № 1 дещо знижувалися, що характеризувало позитивний вплив обраної композиції на консистенцію та соковитість. Співвідношення інгредієнтів, характерне для рецептури № 2, свідчить про ефективну заміну м'ясної сировини 3 одночасним здешевленням готового продукту, що у наш час $€$ не менш актуальним.

\section{Бібліографічні посилання}

Syicheva, O.V. Konoplev, V.I., Veselova, M.V. (2010). Povyishenie tochnosti organolepticheskoy otsenki. Dostizheniya nauki i tehniki APK. 12, 79-80 (in Russian).

Magzumova, N.V. (2012). Sovershenstvovanie tehnologii proizvodstva varenyih kolbas $\mathrm{s}$ primeneniem rastitelnyih belkov. Izvestiya vuzov. Pischevaya tehnologiya. 2-3, 58-60 (in Russian).

Strashynskiy, I., Fursik, O., Pasichniy, V., Marynin, A., Goncharov, G. (2016). Influence of functional food composition on the properties of meat mince systems». Eastern-European Journal of Enterprise Technologies. (Technology and Equipment of Food Production). Kharkiv: Technology center. 6, 11(84), 53-58.

Strashynskyi, I.M., Pasichnyi, V.M., Dubkovetskyi, I.V., Fursik, O.P. (2015). Doslidzhennia vlastyvostei hotovykh vyrobiv $\mathrm{z}$ vykorystanniam funktsionalnoi kharchovoi kompozytsii». Naukovyi visnyk LNUVMBT imeni S.Z. Hzhytskoho. 17, 4(64), 136141 (in Ukrainian).

Стаття надійшла до редакиії 16.02.2017 